\title{
REPRODUCIBLE ABILITY AND MEAT PRODUCTIVITY OF CATTLE OF THE MEN-ANJOU BREED IN THE STEPPE ZONE OF UKRAINE
}

\section{V.S. Kozyr}

SE Institute of Grain Crops of National Academy of Agrarian Sciences, 14 Volodymyr Vernadskyi Str., Dnipro, 49027, Ukraine

Studies have been carried out on the possibility of raising cattle of the Men-Anjou breed in the conditions of the steppe zone of Ukraine. It is proved that animals are well acclimatized to the hot climate of the south - body temperature, respiration rate and pulse rate remain normal. However, their habitus somewhat decreases in comparison with analogues in the homeland of France). This process we called "graduation", as a result of which the amount of moisture in the muscles, fat and bones is less. But the reproductive capacity of the breeding stock and the sexual activity of bulls-producers does not deteriorate. Meat production and slaughter indicators remain high.

When using this meat breed in industrial cross with dairy breeds, the obtained crosses (F1 and F2) showed good fattening qualities, which increases the production of high-quality beef.

Key words: breed, acclimatization, reproductive ability, productivity, meat qualities.

Men-Anjou, red-motley suit (second name red meadow) - one of the largest french and world breeds of cattle for live weight, body length and height $[1,2]$. Taking into account that the climatic and fodder conditions of northwestern French differ significantly from the steppe zone of Ukraine, the study of biological and economic characteristics, their adaptation and meat productivity in this region is actuality.

Material and methods. The bull-calfs (7 heads) and the heifer (20 heads) lines of Dalby, Paver, Nino and Uplaite were imported from Belarus to agroformation «Ukraine» of the Dnipro-petrovsk region. Observations were conducted until they reached 36 months of age. Rations were balanced by nutrients and mineral substances at the expense of traditional feed (straw and green mass of winter crops, hay and haylage from alfalfa, green mass and corn silage, and feed). Animals were kept all year round indoors on straw bedding with free access to the walking and stern area, in the summer (MaySeptember) grazed on natural pastures. Calves were grown on the suction until 6 months of age. Only in bad weather (rain, wind, snow) the cat was freely entering the premises.

Research results. From the fertilized in Belarus heifer, the bull-calfs were born with a live weight of $53 \mathrm{~kg}$ (individual weighed more than $60 \mathrm{~kg}$ ), heifers - $46 \mathrm{~kg}$ (individual over $50 \mathrm{~kg}$ ). There have been cases of necessary assistance in the calving $[3,4,5]$. The further ukrainian generation was much smaller: bullcalfs $-47 \mathrm{~kg}$, heifers $-41 \mathrm{~kg}$.

It is believed that from the Men-Anjou, as well as with other imported classical beef breeds (Sharole, Hereford, Aberdeen-Angus, Limousine, light Aquitaine), there was a "stepping", as a result of which the habitats of the animals became smaller, the younger ones were born smaller, the hotels passed It is easier but its growth energy remained at the level of the breed standard. Sexual maturity of bull-calfs was manifested at 12 months of age, heifers - 18 months, with a live weight of $450 \mathrm{~kg}[6,7]$.

The live weight of cows was within 600$700 \mathrm{~kg}$ of the elite class (integrated score of 89).

For the body structure - in comparison with raion dairy cattle, these are large animals (257 heavy weight index, 156 massiveness), compact (138 loss index), harmonic (113 stretch index), broad and deep breast (broad-breed index 37 , dehydration - 51), the back of the body is well developed (hip index - 90, awl - backside - 60).

Grown bulls have a live weight of 800$1000 \mathrm{~kg}$ (a record in France and the world-1700 $\mathrm{kg}$ ), while hunted into the elite class (91 points).

\footnotetext{
Інформація про авторів:

Kozyr Volodymir Semenovich, doctor of agricultural sciences, professor, academician of NAAS, chief sicientist collaborator of laboratory animal husbandry, e-mail: izkzoo3337@ gmail.com, http://orcid.org/0000-0002-0275-475X
} 
They are high (height at the withers is $170 \mathrm{~cm}$ ) and long (torso length up to $175 \mathrm{~cm}$ ), broadnecked (up to $65 \mathrm{~cm}$ ) and deep-necked (up to 80 $\mathrm{cm}$ ) with well-developed meat forms behind (width $70 \mathrm{~cm}$ ). The temperament is calm.

The character positively characterizes reproductive ability [8]. The first calving took place in 27-30 months, service period - 65-70 days, which allows the calves to receive annually (interjection period does not exceed 12 months). As a rule, bulls are born $-60 \%$, calf $40 \%$. The placenta is separated in 40-80 minutes, and the involution of the genital organs is completed 3 weeks after the calving and the animals immediately come to willingly. Unlike some breeds of meat, they show a high maternal dominant and careful attitude towards the descendants. Peaceful behavior does not prevent cows from actively protecting their offspring from other animals and do not allow strangers to suck their own but are friendly towards humans. Mother massages the newborn tongue until he begins to suck his breast independently, receiving colostrum, which (like milk) is sufficient to grow a healthy offspring (milk yield $2500 \mathrm{~kg}$, fat content of $3.7 \%$ ).

1. Development of animals of the breed of Men-Anjou, $X \pm S_{x}$

\begin{tabular}{|c|c|c|c|c|c|c|c|c|}
\hline \multirow{2}{*}{ Indexes } & Sex & \multicolumn{7}{|c|}{ Age, monts } \\
\cline { 2 - 9 } & at birth & 6 & 12 & 18 & 24 & 30 & 36 \\
\hline $\begin{array}{c}\text { Live } \\
\text { weight, } \\
\text { kg }\end{array}$ & bull-calf & 47 & $216 \pm 3$ & $398 \pm 7$ & $579 \pm 8$ & $723 \pm 12$ & $811 \pm 17$ & $874 \pm 12$ \\
\cline { 2 - 9 } & calf-cow & 41 & $203 \pm 5$ & $329 \pm 6$ & $474 \pm 9$ & $566 \pm 11$ & $630 \pm 10$ & $681 \pm 14$ \\
\hline $\begin{array}{c}\text { Average } \\
\text { gain for } \\
\text { previous } \\
\text { period, g }\end{array}$ & bull-calf & - & 939 & 1014 & 1005 & 803 & 489 & 352 \\
\cline { 2 - 9 } & calf-cow & - & 900 & 701 & 804 & 511 & 357 & 283 \\
\hline
\end{tabular}

For all time observations of animals developed normally (death was not), as evidenced by the dynamics of live weight and average daily increments (Table 1).

Ethological studies confirm a calm, to some degree even phlegmatic status of the nervous system. The young from the first months of life is not active (bulls are a little more moving than the heifers).

The data in Table 1 indicate that the Men-Anjou breed is long-growing and shows high growth energy up to 2.5 years of age and in hot, dry conditions of the steppe zone of Ukraine. The average daily gain during this period of Bullcalf growth was $835 \mathrm{~g}$ (Table 2).

The achievement of a higher living weight at a young age is very important in the economic assessment of the breed - reducing the period of growing animals to difficult conditions greatly increases the efficiency of the use of capital investments and feed (due to a significant dynamic decline in the cost of age rations). At the same time, the cost of feed for 1 metric center of growth within the norm at their eating rate $-99 \%$. Regardless of the fact that in the feeder (even the remains of animals from a dairy farm), this cattle eats everything and struggles for the place and there is no front feeding.

In the post-dairy period, the cost of 1 ts of gain is $70-110 \mathrm{MJ}$ (with an increase in the age of animals and their live weight, this figure increases). Up to 18-20 months of age from bull-calf per $1000 \mathrm{MJ}$ receive $13-14 \mathrm{~kg}$ of gain, and in 20-30 months - 8-9 kg. Live animals weighing up to $300 \mathrm{~kg}$ spend on a $1 \mathrm{~kg}$ gain less than $70 \mathrm{MJ}$, from 300 to $400-80$, from 400 to $500 \mathrm{~kg}-90$, from 500 to $600 \mathrm{~kg}-110$, from 600 to $700 \mathrm{~kg}-130$, from 700 to $800 \mathrm{~kg}-150$ and more than $800 \mathrm{~kg}-180 \mathrm{MJ}$.

Bulls of the Men-Anjou breed have good mortality rates - the slaughter output is $63-65$ $\%$, the meatiness ratio is 5.3-5.6 and the yield of pulp in the carcasses is $81-83 \%$ (with age these figures increase). The presence of moisture in meat is lower than that of analogues grown in countries with humid climates. This process is called "stepping" in the conditions of the steppe zone of Ukraine.

The tasting evaluation and culinary qualities of meat and broth with the age of animals 


\section{Age of animals when reaching the corresponding live weight (days), $X \pm S_{x}$}

\begin{tabular}{|c|c|c|}
\hline Indexes & \multicolumn{2}{|c|}{ Days } \\
\hline Live weight, $\mathrm{kg}$ & bulls & heifers \\
\hline 300 & $269 \pm 6$ & $324 \pm 5$ \\
\hline 400 & $368 \pm 7$ & $455 \pm 8$ \\
\hline 500 & $469 \pm 9$ & $601 \pm 10$ \\
\hline 600 & $577 \pm 12$ & $825 \pm 14$ \\
\hline 700 & $701 \pm 16$ & - \\
\hline 800 & $888 \pm 27$ & - \\
\hline
\end{tabular}

and the increase in live weight is somewhat reduced, but not so much as to affect their consumer properties (4,5 points).

Animals of the Maine-Anjou breed, as well as other clear breeds, are characterized by the phenomenon of bonits - the excess of the live weight of live animals over the actual sales of meat-processing enterprises and mutual payments for slaughtered output, which is due to higher carcass yields.

We have carried out the trial experiments with the use of bulls in industrial crosses with the royal stock of red, red-rumpy milk and Simmental cattle $[9,10]$. Local calves are born smaller, but heavier than pure-breed dairy and combined breeds (bulls $-40 \mathrm{~kg}$, heifers $-35 \mathrm{~kg}$ ). At the same time there was no need for help with

\section{Використана література}

1. Гончаренко I. М'ясне скотарство провідних країн Європи. Тваринництвво України. 1997. № 4. C. 30 .

2. Смирнов Д. Мясная порода скота Мен-Анжу. Молочное и мясное скотоводство. 1980. № 5. C. 44

3. Телюк С. Н. Хозяйственно физиологические особенности породы Мен-Анжу в условиях Белоруссии. Животноводство и ветеринарная медиичина. 1998. № 2. С. 78-80.

4. Кароба В. И., Палько В. В., Борисов В. М. Разведение сельскохозяйственных животных / Белорусская гос. с.-х. акад. Горки, 2005. С. 84-89.

5. Квитковская А. В. Акклиматизационные способности скота породы Шароле и Мен-Анжу в природно-климатических условиях Белоруссии: автореф. дис. ... канд. с.-х. наук. Жодино, 1984. $22 \mathrm{c}$.

6. Винничук Д. Т. Основы зооинженерии, Москва: ACT, 2004. 197 c.

7. Сірацький Й. 3. Методи оцінки відтворювальної здатності худоби. Київ: Аграр. наука, 2015. C. $175-178$.

8. Доротюк Э. Н., Горин А. В. Улучшение воспроизводства в мясном скотоводстве. Животновод- hospitality. An animal-age segment becomes more cost-effective [11].

\section{Conclusions}

1. In the steppe zone of Ukraine, bull-calf of the Men-Anjou breed should be grown up to 30 months of age in a voluminous and grazing land, and sold for slaughter with a live weight of up to $800 \mathrm{~kg}$.

2. It should be considered the main direction of selection work with the breed of Men-Anjou - pure breeding and the use of bullsbreeding for industrial crossing with red and red-rash milk and Simmental cattle.

3. For the steppe zone, the Men-Anjou breed is not only a source of high-quality beef production but also a genetic diversity in the breeding process.

ство. 1983. № 9. С. 57-58.

8. Казоровец П. В. Эффективность промышленного скрещивания симментальского скота с производителями породы Мен-Анжу: дис. ... канд. с.-х. наук. Жодино, 1984. 168 с.

9. Мельник Ю. Ф. Формування м'ясної продуктивності у тварин різних порід великої рогатої худоби, яких розводять в Україні. КорсуньШевченківський, 2010. 298 с.

10. Олийник С. О. Шляхи рентабельного розведення м'ясного скотарства в степовій зоні. Вісн. аграр. науки. 2003. № 2. С. 39-42.

\section{Referens}

1. Goncharenko, I. (1997). Meat cattle breeding in the leading countries of Europe. Tvarynnytstvo Ukrainy [Livestock breeding in Ukraine], 4, 30. [in Ukrainian]

2. Smirnov, D. (1980). Meat-breeding cattle of MenAnjou. Molochnoe I myasnoe skotovodstvo [Dairy and meat cattle breeding], 5, 44. [in Ukrainian]

3. Telyuk, S. N. (1998). Economic and physiological features of the breed of Men-Anjou in the conditions of Belarus. Zhyvotnovodstvo $i$ veterinarnaia meditsyna [Livestock breeding and veterinary medical], 2, 78-80. [in Russian] 
4. Karoba, V. I., Palko, V. V., Borisov, V. M. (2005) Razvedenie selskokhoziaistvennykh zhyvotnykh [Breeding of farm animals], Gorki: N. p., 84-89. [in Russian]

5. Kvitkovskaya, A. V. (1984). Acclimatizationnye spsobnosyi skota porody Charolais and Men-Anzhu v prirodno-klimaticheskikh usloviyakh Belarusi [Acclimatization abilities of the livestock of the Charolais and Men-Anjou breeds in the natural and climatic conditions of Belarus] (Extended Abstract of Cand. Agric. Sci. Diss.). Zhodino, Belarus. [in Russian]

6. Vinnichuk, D. T. (2004). Osnovy zooinzhenerii [Fundamentals of zoinengery]. Moscow: AST. [in Russian]

7. Syaratsky, Y. Z. (2015). Metody otsinky vidtvoruvalnoi zdatnosti khudoby [Methods for assessing the reproductive capacity of livestock]. Kyiv, Agrarian science, 175-178. [in Ukrainian]
8. Dorotyuk, E. N., Gorin, A. V. (1983). Improvement of reproduction in meat cattle breeding. Zhyvotnovodstvo [Livestock breeding], 9, 57-58. [in Russian]

9. Kazorovets, P. V. (1984). Efektivnost promyshlennogo skreshshivania sementalskogo skota s proizvoditeliami porody Men-Anzhu [Efficiency of the industrial crossing of Simmental livestock with the producers of the Men-Anjou breed] (Cand. Agric. Sci. Diss.). Zhodino. Belarus. [in Russian]

10. Melnyk, Yu. F. (2010). Formuvannia miasnoi produktyvnosti u tvaryn riznykh porid velykoi rogatoi khudoby, akykh rozvodiat $v$ Ukraini [Formation of meat productivity in animals of different breeds of cattle breeding in Ukraine]. Korsun-Shevchenkivskyi: N. p. [in Ukrainian]

11. Oliynyk, S. O. (2003). Ways of cost-effective breeding of meat cattle breeding in the steppe zone. Visnyk agrarnoi nauky [Bulletin of Agrarian Science], 2, 39-42. [in Ukrainian]

\section{УДК 636.2.062}

Козырь В. С. Воспроизводительная способность и мясная продуктивность скота породы МенАнжсу в степной зоне Украины. Зерновые культурыл. 2018. T. 2. № 2. С. 382-385.

Государственное учреждение Институт зерновых культур НААН, ул. Владимира Вернадского, 14, 2. Днепр, 49027, Украина

Освещзены результаты научных исследований по выращчиванию крупного рогатого скота породы Мен-Анжу в кормовых условиях степной зоны Украиныл. Доказано, что животные, родиной которых является приморская зона Франциии, где умеренный влажный климат, хорошо акклиматизировались к жаркому климату юга - температура тела, частота дыхания и пульса остаются нормальными. Однако габитус их несколько уменьшается в сравнении с аналогами на родине. Этот процесс мы назвали «остепнением», результатом которого является уменьшение количества влаги в мышицах, жире и костях, но при этом воспроизводительная способность маточного поголовья и половая активность быков-производителей не ухудшаются. Мясная продуктивность и убойные показатели остаются высокими и не уступают мировым классическим мясным породам.

При использовании этой мясной породы в промышленном скрещчивании с районированными украинскими молочными породами, полученные помеси $\left(F_{1}\right.$ u $\left.F_{2}\right)$ проявили хорочие откормочные качества, что способствует увеличению производства высококачественной говядины и обеспечению продовольственной безопасности страны.

Ключевые слова: порода, акклиматизация, воспроизводительная способность, продуктивность, мясные качества.

\section{УДК 636.2.062}

Козир В. С. Відтворна здатність $і$ м'ясна продуктивність худоби породи Мен-Анжу в степовій зоні України. Зернові культури. 2018. T. 2. № 2. С. 382-385.

Державна установа Інститут зернових культур НААН, вул. Володимира Вернадського, 14, м. Дніпро, 49027, Україна

Висвітлені результати дослідження можливості вирощування великої рогатої худоби породи Мен-Анжу в умовах степової зони України. Доведено, шуо тварини добре акліматизувались до жаркого клімату півдня - температура тіла, частота дихання $і$ пульсу в нормі. Але габітус їх дещо зменшується порівнянно з аналогами на батьківщині (Франція). Цей процес ми назвали „остепнінням" - його результатом є зменшення кількості вологи в м'язах, жиру і кістках. Однак відтворна здатність маточного поголів'я $і$ статева активність бугаїв-плідників не погіршуються. Мяяна продуктивність $і$ забійні показники залишаються високими.

При використанні иісї м'ясної худоби у промисловому схрешуванні з районованими молочними породами одержані помісі $\left(F_{1}\right.$ i $\left.F_{2}\right)$ проявили добрі відгодівельні якості, шуо зумовлює збільшення виробництва високоякісної яловичини.

Ключові слова: порода, акліматизація, відтворювальна здатність, продуктивність, м’ясні якості. 